\title{
Alleviate Effect of Pomegranate Peel Extract in Ameliorating Fluoride-Induced Cytotoxicity, Oxidative Stress in Tetrahymena pyriformis Model
}

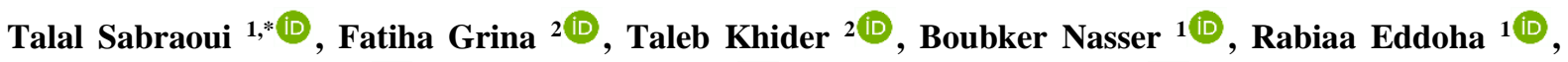 \\ Abderahman moujahid ${ }^{1}{ }^{(\mathbb{D})}$, Maryem Benbachir ${ }^{1}{ }^{\mathbb{D}}$, Abdelkhalid Essamadi ${ }^{1(\mathbb{D})}$ \\ 1 Hassan $1^{\text {st }}$ University, Faculty of Sciences and Technology, Laboratory of Biochemistry \& Neurosciences, Applied \\ Biochemistry and Toxicology Team, 26000 Settat, Morocco \\ 2 Food Chemistry, Department of Chemistry and Pharmacy, Emil Fischer Center, Friedrich-Alexander Universität Erlangen- \\ Nürnberg (FAU), Nikolaus-Fiebiger-Straße 10, 91058 Erlangen, Germany \\ * Correspondence: t.sabraoui@uhp.ac.ma (T.S.);
}

Scopus Author ID 57218995530

Received: 3.05.2021; Revised: 10.06.2021; Accepted: 15.06.2021; Published: 13.08.2021

\begin{abstract}
Fluoride is a major oligo element found in nature, at excessive amounts can cause enormous harm in mammalian cells. Fruits peel, considered most often as a waste of juice processing, could play an important role in attenuating metal cytotoxicity. The present study evaluated the effect of pomegranate peel (Punica granatum. L) methanolic extract (PPE) on the Fluoride-induced toxicity and redox status in the protozoa Tetrahymena pyriformis. Polyphenols of peel extract were extracted using methanol and characterized by spectrophotometric methods, total phenolic content (TPC), total flavonoids content (TFC), and in vitro, antioxidant properties were assessed using the Folin-Ciocalteu method and DPPH, ABTS, and FRAP. Pomegranate peel is a rich source of phenolic compounds TP (223.21 $\pm 15 \mathrm{mg} \mathrm{GAE} / \mathrm{g} \mathrm{dw})$, TF (52.12 $\pm 1.36 \mathrm{mg} \mathrm{Qu} / \mathrm{g} \mathrm{dw})$ and showed high antioxidant properties DPPH $\left(\mathrm{EC}_{50} 0.043 \pm 0.06 \mathrm{mg} / \mathrm{ml}\right)$, ABTS $\left(\mathrm{EC}_{50} 0.06 \pm 0.01 \mathrm{mg} / \mathrm{ml}\right)$ and FRAP $(1.47 \pm 0.01 \mathrm{mg}$ AA equivalents/g dw). Cells were incubated with fluoride alone and in combination with PPE. NaF $(0.8$ $\mathrm{mM}$ ) significantly decreased the cell viability, induced oxidative stress by decreasing antioxidants enzyme activities, and increased intracellular fluoride content. Treatment with $\mathrm{NaF}$ in combination with PPE decreases CAT, SOD, and GPx activities and alleviates GSH content. These findings suggest that pomegranate peel biomolecules may have a protective effect against fluoride induced-toxicity.
\end{abstract}

Keywords: fluoride; Punica granatum; punicalagins; antioxidant.

(C) 2021 by the authors. This article is an open-access article distributed under the terms and conditions of the Creative Commons Attribution (CC BY) license (https://creativecommons.org/licenses/by/4.0/).

\section{Introduction}

Fluorine (F) represents $0.06-0.09 \%$ of earth's crust, found in nature in its inorganic and organic forms as Fluoride [1]. Due to the high electronegativity of this halogen, fluoride can interact with many cations, including hydrogen and a wide variety of metals, and therefore exists in acidic environments as its protonated form (HF). The main source of fluoride administration is drinking water in rural areas, especially areas surrounding phosphate production and aluminum manufacture [2-3]. Its deleterious impacts on health are evident in large areas of the world. Morocco is the leading producer and exporter of phosphate, and its derivate from the world, sharing about $30 \%$ of the global market [4].

Phosphate fertilizers synthesized from phosphate rocks contain different fluoride rocks as fluorite $\left(\mathrm{CaF}_{2}\right)$ or fluorapatite $\left(\mathrm{Ca}_{2}\left(\mathrm{PO}_{4}\right)_{3} \mathrm{~F}\right)$ [5], which are suggested to be the main source 
of contamination of groundwater by fluoride [6,7]. A study by Jaudi et al. showed that more than half $(53 \%)$ of the wells exceeded the upper limit set by WHO (1.5 mg / 1) [8]. The groundwater is supposedly the main source through which people are highly exposed to fluoride, compared with other sources of exposure. At low doses, Fluoride is necessary to maintain the structure and physiological function of bones and teeth [9-11]. However, excessive fluoride is toxic to soft tissues [12,13] and may cause health problems, including dental fluorosis, osteoporosis, and bone sclerosis [6-7]. Nevertheless, long exposure to fluoride can be harmful to mammalian nervous, reproductive, and immune systems [14-16], and may cause cell death and alteration of the antioxidant defense system and influence metabolism of lipids [17-18]. The primary mechanism involved in fluoride toxicity can be attributed to the oxidative stress caused by this halogen [19]. Commonly confirmed in previous studies, fluoride exposure induces the generation of free radicals, consequently causing the oxidation of macromolecules to which can lead to fragile membrane phospholipids, mitochondrial membrane depolarization, and apoptosis [20-21]. In addition, the accumulation of fluoride can inhibit the activity of antioxidant enzymes, such as SOD, CAT, and GPx [22,23].

In recent years, an increase of interest in search of fruits bioactive molecules, pomegranate (Punica granutum L.) is accepted as a unique fruit having considerably high antioxidant activity. Different parts contain valuable compounds, such as peel, arils, and seeds [24-25]. This valuable fruit is a rich source of polyphenols as hydrolyzable tannins, condensed tannins, flavonols, anthocyanins, and phenolic and organic acids [26], peel as the non-edible part of the fruit represents $50 \%$ and is characterized by antioxidant capacity compared to the edible part of the fruit consisted of $10 \%$ seeds and $40 \%$ arils [27]. The antioxidant capacity of the pomegranate has been attributed to its two major compounds: punicalagin and ellagic acid. These isomers constitute over $85 \%$ of tannins present in the peel [28,29]. The biological properties of pomegranates promoted us to evaluate their effect on NaF-induced toxicity in a protozoa model. Tetrahymena pyriformis, ciliated protozoa that could be found in freshwater, is a eukaryotic cell well establish as a suitable model of eco-toxicological studies and especially in aquatic ecosystems [30]. Therefore, our study aims to determine the dose-dependant of fluoride and evaluate whether an extract from pomegranate peel can exhibit a protective effect against the acute toxicity of fluoride.

\section{Materials and Methods}

\subsection{Chemicals.}

All chemicals and reagents were purchased from Sigma-Aldrich Chemistry (Germany).

\subsection{Fruit samples and extraction procedure.}

Mature pomegranate fruit was purchased from a local market in old Abdellah, Beni Mellal province of Morocco $\left(32^{\circ} 29^{\prime} 32.4^{\prime \prime} \mathrm{N} \mathrm{6}^{\circ} 27^{\prime} 05.6^{\prime \prime} \mathrm{W}\right)$. Fruits were manually peeled, and collected peels were then rinsed with distilled water. Peel and seed were dried in an oven (Binder, BD 56 Germany) with air circulation at $40{ }^{\circ} \mathrm{C}$, and they were finely ground in a laboratory grinder. The dried sample was then stored at $20^{\circ} \mathrm{C}$ until further use. The peel and seed powder $(10 \mathrm{~g})$ was extracted with $60 \mathrm{~mL}$ of methanol by magnetic stirring at room temperature for $24 \mathrm{~h}$. The extracts were filtered through Whatman no. 41 filter paper for the removal of particles. The residue was re-extracted with $50 \mathrm{~mL}$ of methanol and filtered. The pool of extracts was concentrated under a vacuum at $40{ }^{\circ} \mathrm{C}$ (Rotary evaporator Buchi R-210) 
to obtain the final extracts: Pomegranate Peel Extract (PPE) and Pomegranate Seed Extract (PSE) [31].

\subsection{Determination of total phenols and total flavonoids.}

The total phenolic content was determined by the Folin-Ciocalteu method Singleton \& Rossi. Briefly, pomegranate extracts $(0.2 \mathrm{mg})$ were mixed with $1.0 \mathrm{~mL}$ of 10 -fold diluted FolinCiocalteu reagent. After 3 to $5 \mathrm{~min}, 0.8 \mathrm{~mL}$ of a $7.5 \%$ (w/v) sodium carbonate solution were added, and the mixture was left to stand for $30 \mathrm{~min}$ at $30^{\circ} \mathrm{C}$, then the absorbance was measured at $765 \mathrm{~nm}$ using a Genesys-5 UV-visible spectrophotometer, and results were expressed as $\mathrm{mg}$ of Gallic acid equivalents (GAE) per gram of dry extract [33]. Determination of flavonoid content is based on the formation of the complex flavonoid and aluminum. Briefly, $0.5 \mathrm{ml}$ of both peel and seed extract were mixed $0.5 \mathrm{ml}$ aluminum chloride $2 \%$, then $3 \mathrm{ml}$ of potassium acetate 5\% (Merck, Germany) was added. After $40 \mathrm{~min}$ at room temperature and the absorbance was measured at $415 \mathrm{~nm}$, results are expressed as rutin equivalents in $\mathrm{mg} / \mathrm{g}$ [33].

\subsection{Antioxidants properties.}

\subsubsection{DPPH free radical scavenging assay.}

Radical DPPH scavenging capacity was estimated from the difference in absorbance with or without antioxidants and expressed as percent DPPH disappearance due to the sample concentration [34]. Briefly, different concentrations (50 and $100 \mathrm{ppm}$ ) of pomegranate peel were taken in different test tubes. The volume was adjusted to $100 \mu \mathrm{L}$, by adding methanol. Then $5 \mathrm{~mL}$ of a $0.1 \mathrm{mM}$ methanolic solution of DPPH was added to these tubes and shaken vigorously [32]. After incubation at $27^{\circ} \mathrm{C}$ for $20 \mathrm{~min}$, absorbance was measured at $517 \mathrm{~nm}$. The radical scavenging activity is expressed as the following formula: RSA $(\%)=($ control OD sample OD/control OD) $\times 100$. The antioxidant activity was calculated as the effective concentration at $50 \%\left(\mathrm{EC}_{50}\right)$ of a sample required to decrease the absorbance by $50 \%$.

\subsubsection{ABTS cation radical assay.}

ABTS assay was based on the method of Ramos et al. [35] with slight modifications. Briefly, the radical ABTS solution was prepared by mixing an equal volume of ABTS stock solution $7 \mathrm{mM}$ with $2.45 \mathrm{mM}$ of potassium persulfate. The mixture was allowed to stand for 16 hours at room temperature in the dark. Before been used, different concentrations of this solution in acetate buffer $(\mathrm{pH} 4.650 \mathrm{mM})$ were prepared to obtain an absorbance of $0.700 \pm$ 0.02 at $734 \mathrm{~nm}$. The assay was performed in a 96-well microplate. Hence $150 \mu \mathrm{L}$ of the diluted sample was added to the plate, followed by adding $150 \mu \mathrm{L}$ of the ABTS solution. Absorbance was measured after 6 min by spectrophotometer (Synergy HT, Bio-Tek Instruments, Winooski, VT, USA). ABTS scavenging percentage was calculated using the following equation: ABTS scavenging $(\%)=\left(\right.$ control OD - sample OD/control OD) $\times 100$. The $\mathrm{EC}_{50}$ values were calculated from standard curves. 
2.5. Chelating activity.

2.5.1. Ferric reducing power assay (FRAP).

Determination of the ferric reducing antioxidant power (FRAP) was based on the method by Oyaizu et al. $500 \mu \mathrm{L}$ of peel and seed were added to $1.25 \mathrm{~mL}$ of phosphate buffer (0.2 M, pH 6.6), $1.25 \mathrm{~mL}$ of ferricyanide potassium is added to each tube, followed by 1.25 $\mathrm{mL}$ of trichloroacetic acid $(10 \% \mathrm{v} / \mathrm{v})$. The mixture is incubated at $50^{\circ} \mathrm{C}$ for $15 \mathrm{~min}$, the mixture was diluted in distilled water (1/2), and $0.25 \mathrm{~mL}$ of ferric chloride $1 \%$ was added, absorbance was measured at $700 \mathrm{~nm}$, and results are expressed as equivalent $\mathrm{mg}$ ascorbic acid (AAE) per $100 \mathrm{~g}$ of dw [36].

\subsection{2. $\mathrm{Fe}^{2+}$ Chelating Activity Assay.}

Pomegranate peel and seed extracts of ferrous ions $\mathrm{Fe}^{2+}$ were measured using the method described by Dinis et al. [37]. Briefly, $0.5 \mathrm{~mL}$ of extract at different concentrations were added to $1.6 \mathrm{~mL}$ of distilled water and $0.05 \mathrm{~mL}$ of $\mathrm{FeCl}_{2}(2 \mathrm{mM})$ were added, followed by adding $0.1 \mathrm{~mL}$ Ferrozine $(5 \mathrm{mM})$. The mixture is incubated at room temperature for $10 \mathrm{~min}$, a complex of $\mathrm{Fe}^{2+}$ and Ferrozine complex was measured at $562 \mathrm{~nm}$. The chelating activity of the extract was calculated using the following equation: Metal chelating activity $(\%)=(\mathrm{OD}$ control - OD sample/ OD control) $\times 100$. The results were expressed as $\mu$ mol of EDTA equivalent/g of dry weight.

\subsection{Protective effect of pomegranate peel extract (PPE) on NaF-induced cytotoxicity.}

2.6.1. Cell culture of tetrahymena pyriformis.

Tetrahymenna pyriformis, strain E, ref ATCC has grown aerobically without shaking to exponential phase at $28^{\circ} \mathrm{C}$ for $72 \mathrm{~h}$ in protease peptone yeast extract (PPY) medium containing ( $1.5 \%$ protease-peptose, $0.25 \%$ yeast extract), at $\mathrm{pH}=7.4$ [38]. For all experiments, the density of cells was adjusted to $5 \times 10^{3} / \mathrm{ml}$.

\subsubsection{Cell viability assays.}

To study the inhibitory effect of fluoride, pomegranate peel extract, and ascorbic acid, the medium was supplemented with 0,2\% (w/v) D-glucose (PPYG). Cells were supplemented with different concentrations of sodium fluoride $(\mathrm{NaF})(100.200 \ldots .1000 \mu \mathrm{mol})$ to determine the sub-lethal concentration, or pomegranate peel methanolic extract (PPE) $(10,25,50,75,100$ $\mu \mathrm{g} / \mathrm{ml})$, and ascorbic acid as a positive control $(10,25,50,75,100 \mu \mathrm{g} / \mathrm{ml})$ alone. To study the protective effect of PPE on NaF induced toxicity, cells were incubated with $\mathrm{IC}_{50}$ of $\mathrm{NaF}$ combined with different PPE concentrations. After $24 \mathrm{~h}$ of incubation, the viability of cells was measured using mitochondrial succinate dehydrogenase activity. The purple color formazan product was measured at $570 \mathrm{~nm}$. The percentage of inhibition was calculated compared to untreated cells, and the Inhibitory concentration $\mathrm{IC}_{50}$ of $\mathrm{NaF}, \mathrm{PPE}$, and ascorbic acid was defined by linear regression analysis.

\subsection{Measurement of intracellular fluoride level.}

Cells $\left(5 \times 10^{3}\right.$ cells $\left./ \mathrm{ml}\right)$ were exposed to $\mathrm{IC}_{50}$ of $\mathrm{NaF}$, and different concentrations of PPE and ascorbic acid below their respective $\mathrm{IC}_{50}$. At the end of treatment, cells were collected 
by centrifugation $(12000 \mathrm{~g}, 15 \mathrm{~min})$ and lysed using the cell lysis buffer (100 $\mathrm{mM}$ Tris- $\mathrm{HCl}$, $50 \mathrm{mM}$ EDTA and 1\% Triton X-100) [39]. The level of Fluoride in the cell lysate was determined with an Orion fluoride ion analyzer (Thermo Fisher Scientific, Waltham, Massachusetts, USA), model 9609, and expressed in mg/L.

\subsection{Measurement of antioxidants enzymes activity, and glutathione assay.}

To evaluate the protective effect of PPE to an oxidative stress induced by fluoride, cells were exposed to $\left(\mathrm{IC}_{50}\right)$ of $\mathrm{NaF}$ and different concentrations of PPE and ascorbic acid below their respective $\mathrm{IC}_{50}$. After 24 hours of incubation, the cells were harvested by centrifugation at $12000 \mathrm{~g}$ for $15 \mathrm{~min}$ at $4^{\circ} \mathrm{C}$, and washed three times with phosphate buffer $\mathrm{pH}=7.4$. The mixture is sonicated with a sonicator (Heidolf Diax 600, Germany) (30s, 2 cycles, $40 \%$ ), and responded in phosphate buffer. The supernatant was collected and used for enzyme activity. Determination of protein was carried out using the method of Lowry et al. [40]. The total activity of superoxide dismutase (SOD) was measured using the method of Beyer \& Fridovich [41]. SOD activity was determined by measuring its ability to inhibit the photo-reduction of nitroblue tetrazolium (NBT); activity is expressed as UI/mg of protein. The activity of catalase (CAT) was measured according to the method of Sinha et al. [42]. The decomposition of $\mathrm{H}_{2} \mathrm{O}_{2}$ was determined by its absorbance decrease at $240 \mathrm{~nm}\left(\varepsilon=39.4 \mathrm{mM}^{-1} \mathrm{~cm}^{-1}\right)$. The total activity of glutathione peroxidase (GSH-Px), according to the method of Battenberg et al. [43], absorbance was recorded at $420 \mathrm{~nm}$. The activity was expressed as $\mu \mathrm{mol}$ of GSH/min $/ \mathrm{mg}$ of protein. The level of glutathione (GSH) was measured using Ellman's method. Reduced thiol contents were expressed in nmol of GSH/mg of protein [44].

\subsection{Statistical analysis.}

Statistical analysis was performed using SPSS 23. Results were expressed as the mean \pm SEM. Comparison between groups was made by one-way ANOVA followed by a Student post hoc test. Differences with values of $p<0.05$ were considered statistically significant.

\section{Results and Discussion}

\subsection{Total phenolic, total flavonoid contents.}

The yield of extraction was found to be $13.24 \pm 1.23 \%$ and $8.23 \pm 0.98 \%$ in peel and seed, respectively total polyphenols ranged from $67.85 \pm 07$ to $223.51 \pm 15 \mathrm{mg} \mathrm{GAE} / \mathrm{g} \mathrm{dw}$. The total flavonoids ranged from $02.11 \pm 0,2$ to $52.12 \pm 1.36 \mathrm{mg}$ rutin/g dw in seed and peeled respectively (Table 1).

Table 1. Phenolic compounds in pomegranate extracts.

\begin{tabular}{c|c|c|c} 
& \% Yield & Total phenolic $(\mathbf{m g ~ G A E} / \mathbf{g})$ & Total flavonoids (mg RE/g) \\
\hline Peel & $13,24 \pm 1,23^{\mathrm{a}}$ & $223.21 \pm 15^{\mathrm{a}}$ & $52.12 \pm 1.36^{\mathrm{a}}$ \\
\hline Seed & $8,23 \pm 0,98^{\mathrm{b}}$ & $67,85 \pm 0,7^{\mathrm{b}}$ & $2,11 \pm 0,02^{\mathrm{b}}$
\end{tabular}

Different letters within the same column are indicating significant differences at $\mathrm{p}<$ 0.05. All data are expressed as mean \pm SD of at least three replicates of each sample. (GAE: gallic acid equivalents. RE: rutin equivalents). 


\subsection{Antioxidants properties and chelating activity.}

DPPH is an artificial radical widely use to determined antioxidant properties of various plant materiel [45]. As shown in (Table 2), scavenging 50\% of the radical is found at a concentration of $\mathrm{EC}_{50}=0.04 \mathrm{mg} / \mathrm{ml}$ in pomegranate peel while $\mathrm{EC}_{50}=0.88 \pm 0.02 \mathrm{mg} / \mathrm{ml}$ in seeds. The antioxidant activity of pomegranate peel using ABTS was found 6.5-fold higher than the one found in seed extracts, thus $\mathrm{EC}_{50}=0,06 \pm 0.01 \mathrm{mg} / \mathrm{ml}$ and $\mathrm{EC}_{50}=0,06 \pm 0.01 \mathrm{mg} / \mathrm{ml}$ in peel and seed respectively (Table 2).

The reducing power was measured using the FRAP assay and $\mathrm{Fe}^{2+}$ Chelating Activity Assay, values expressed as mg ascorbic acid equivalent (AAE)/g of dw of peel or seed are shown in (Table 2). The values varied from 185.56-251.02 mg AAE/100 g for peel, whereas seed showed valued between $0.12-0.20 \mathrm{mg} \mathrm{AAE} / 100 \mathrm{~g}$, whereas $\mathrm{Fe}^{2+}$ Chelating Activity Assay revealed that PPE possesses a $2.29 \pm 0.00 \mu \mathrm{mol}$ EDTA equiv/ $\mathrm{g} \mathrm{dw}$, confirming the higher antioxidant properties of the pomegranate peel.

Table 2. Antioxidants activity of pomegranate extracts.

\begin{tabular}{|c|c|c|c|c|}
\hline & $\begin{array}{c}\text { DPPH assay } \\
\mathrm{EC}_{50}(\mathrm{mg} / \mathrm{mL})\end{array}$ & $\begin{array}{c}\text { ABTS assay } \\
\text { EC }_{50}(\mathrm{mg} / \mathrm{mL})\end{array}$ & $\begin{array}{l}\text { FRAP assay } \\
\text { mg AA/ } 100 \text { g dw }\end{array}$ & $\begin{array}{c}\mathrm{Fe}^{2+} \text { chelating activity } \\
(\mu \mathrm{mol} \text { EDTA equiv/g dw) }\end{array}$ \\
\hline Peel & $0.04 \pm 0.06^{\mathrm{a}}$ & $0,06 \pm 0.01^{\mathrm{a}}$ & $1.47 \pm 0.01^{\mathrm{a}}$ & $2.29 \pm 0.00$ \\
\hline Seed & $0.88 \pm 0.02^{b}$ & $0,40 \pm 0.02^{\mathrm{b}}$ & $0.02 \pm 0.00^{\mathrm{b}}$ & ND \\
\hline
\end{tabular}

Different letters within the same column are indicating significant differences at $\mathrm{p}<$ 0.05. All data are expressed as mean \pm SD of at least three replicates of each sample. (dw: Dry weight, AA : Ascorbic Acid)

\subsection{Cytotoxicity of NaF on T.Pyroformis.}

To evaluate the cytotoxicity of $\mathrm{NaF}$ on T.pyriformis, a range of concentrations of $\mathrm{NaF}$ as mentioned in material and methods were prepared and incubated. Results shown in (Figure.1) demonstrated an increase of cell proliferation by $8 \%(\mathrm{p}<0.05)$ at a concentration of $0.3 \mathrm{mmol}$. However, treatment with concentrations of $\mathrm{NaF}$ above $0.3 \mathrm{mmol}$ induced a significant decrease in cell viability. Moreover, a concentration of 0.8 mmol produced a decrease of $54 \%$ ( $p<0.05$ ) of cell viability after 24 of treatment. Hence, this concentration was chosen for further studies to induce oxidative stress.

\subsection{Effect of pomegranate peel extract on NaF-induced toxicity.}

To establish the non-lethal concentrations of PPE and Vit $\mathrm{C}$ on T.pyriformis. Cells were incubated with PPE and Vit C alone for 24H. As shown in (Figure 2). Extracts of PPE were not toxic to a concentration of $75 \mu \mathrm{g} / \mathrm{ml}$ as well as Vit C. In order to evaluate the protective effect of PPE on NaF-induced cytotoxicity, cells were exposed to $\mathrm{IC}_{50} \mathrm{NaF}, \mathrm{PPE}$, and Vit $\mathrm{C}$ simultaneously. When applied to cells, PPE could significantly restore cell viability to $80.17 \%$ at a concentration of $10 \mu \mathrm{g} / \mathrm{ml}$ and to $67.95 \%$ at $25 \mu \mathrm{g} / \mathrm{ml}$. However, when treated with concentrations above $25 \mu \mathrm{g} / \mathrm{ml}$, PPE had no significant effect on cell viability. 


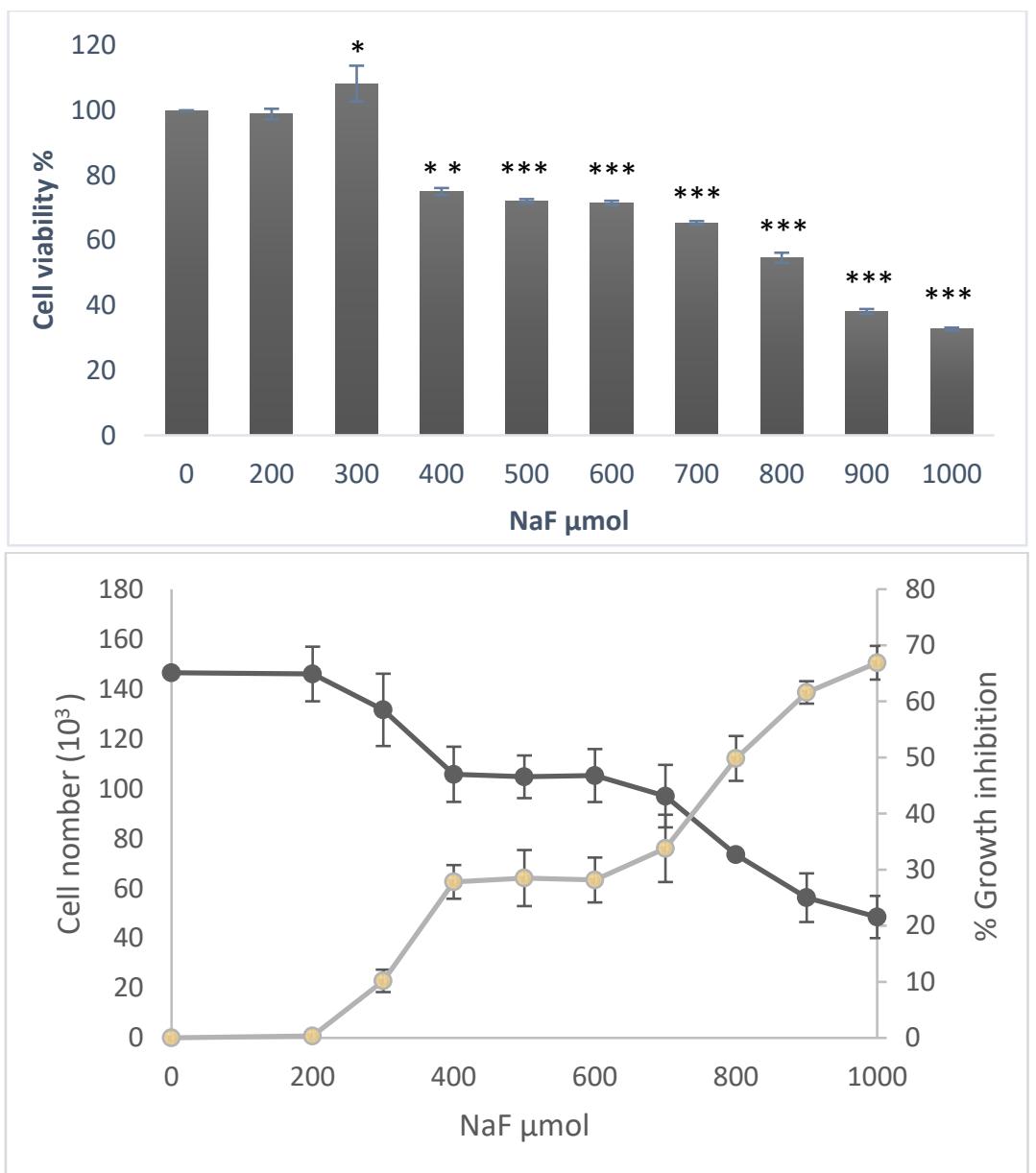

Figure 1. T. pyriformis was cultivated in a PPYG medium in the presence of different concentrations of NaF $(100-1000 \mu \mathrm{M})$. (a) Results were obtained by the MTT method. (b) Effect of NaF on T. pyriformis growth. The results shown are the mean $\pm \mathrm{SD}$ of the three independent experiments. Values were normalized to the control and are given as percent of the control. The significance following the Student-t-test are shown as: $* \mathrm{p}<0.05$; $* * \mathrm{p}<0.01 ; * * \mathrm{p}<0.001$.

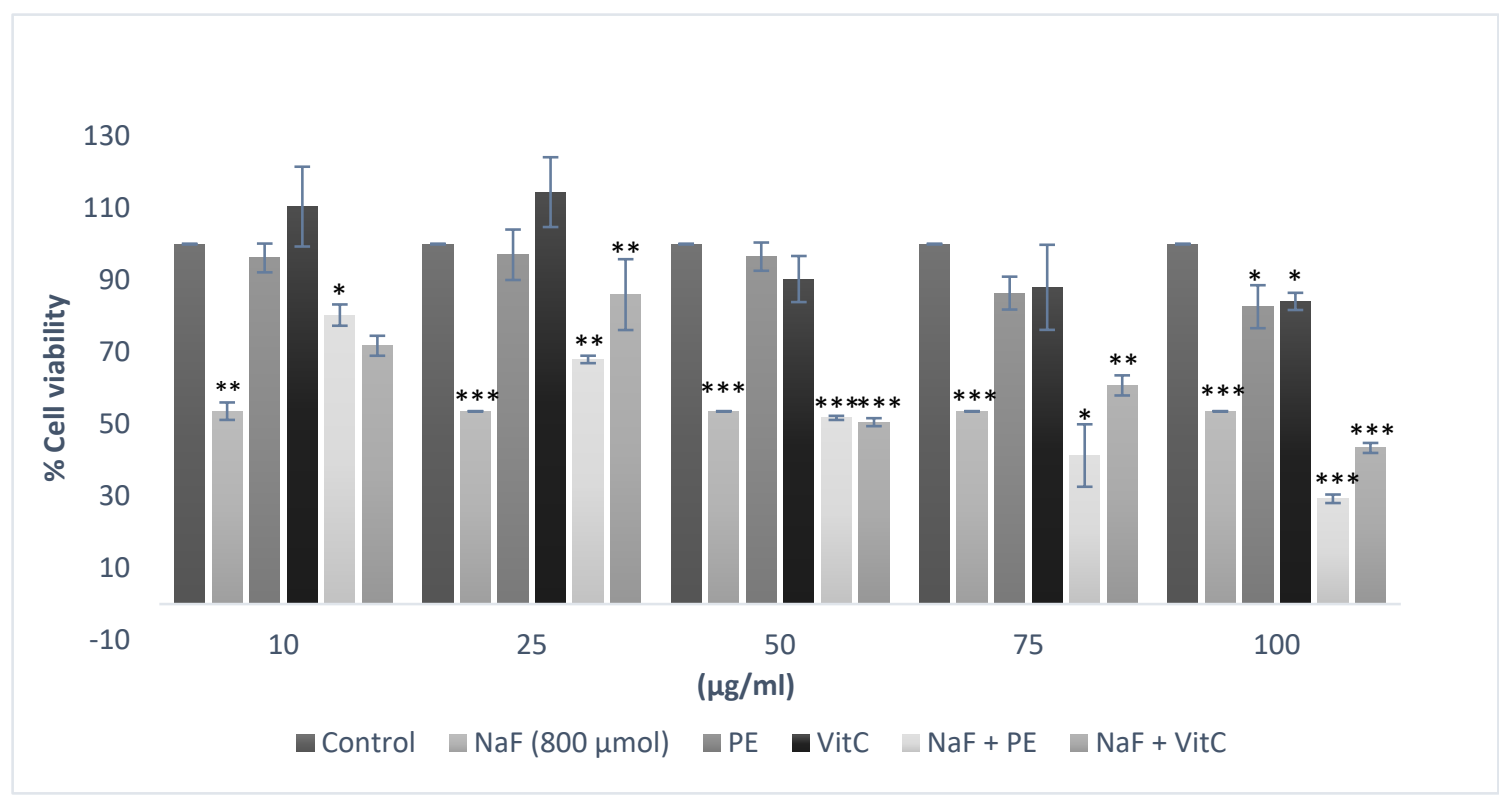

Figure 2. Protective effect of peel extract against $\mathrm{NaF}$ induced oxidative stress condition in T. pyriformis promoted by $\mathrm{NaF}$ at $800 \mu \mathrm{M}$ after 24 hours of incubation. Cell viability was determined via the MTT method.

The values in each column represent the mean \pm standard deviation (S.D). $* \mathrm{p}<0.05, * * \mathrm{p}<0.01, * * * \mathrm{p}<0.001$ represent statistically significant differences compared to control. 


\subsection{Measurement of fluoride level.}

The intracellular fluoride content in $T$. pyriformis treated with $0.8 \mathrm{mmol}$ increased significantly by $411 \%(p<0.05)$ compared to non-treated cells. When cells are treated both with $\mathrm{NaF}$ and PPE, we observed a significant decrease of intracellular fluoride concentration by $79 \%$ ( $p<0.05$ ) compared to cells treated with NaF only (Figure 3 ). The effect of PPE can be compared to those of the positive control (ascorbic acid).

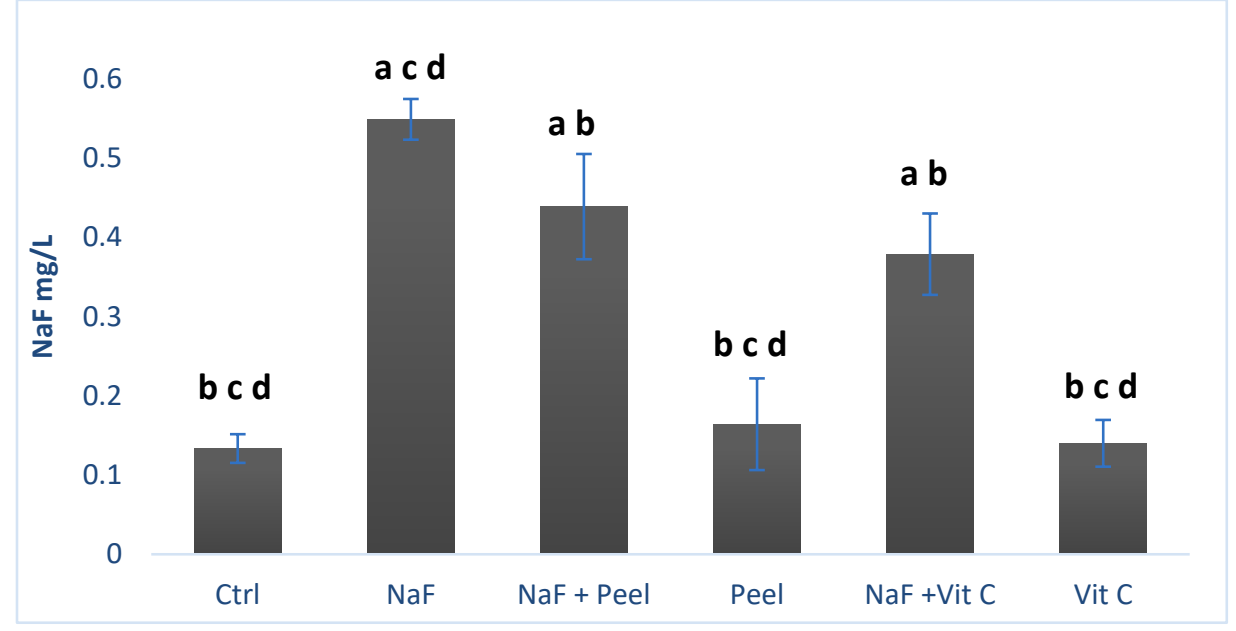

Figure 3. Level of $\mathrm{NaF}$ in cell lysate after $24 \mathrm{~h}$ of treatment, data showed are the mean of three triplicates. Different letters discriminate statistical differences between groups of parameters: a: compared to Ctrl, b: compared to $\mathrm{NaF}$; c: compared to $\mathrm{NaF}+$ peel; d: compared to $\mathrm{NaF}+\mathrm{Vit} \mathrm{C}$.

\subsection{Effect of PPE on antioxidant enzyme activities.}

The present study revealed that treatment with $0.8 \mathrm{mmol}$ lead to a significant decline of SOD activity by $32.64 \%(p<0.05)$ in the group receiving $\mathrm{NaF}$ alone.
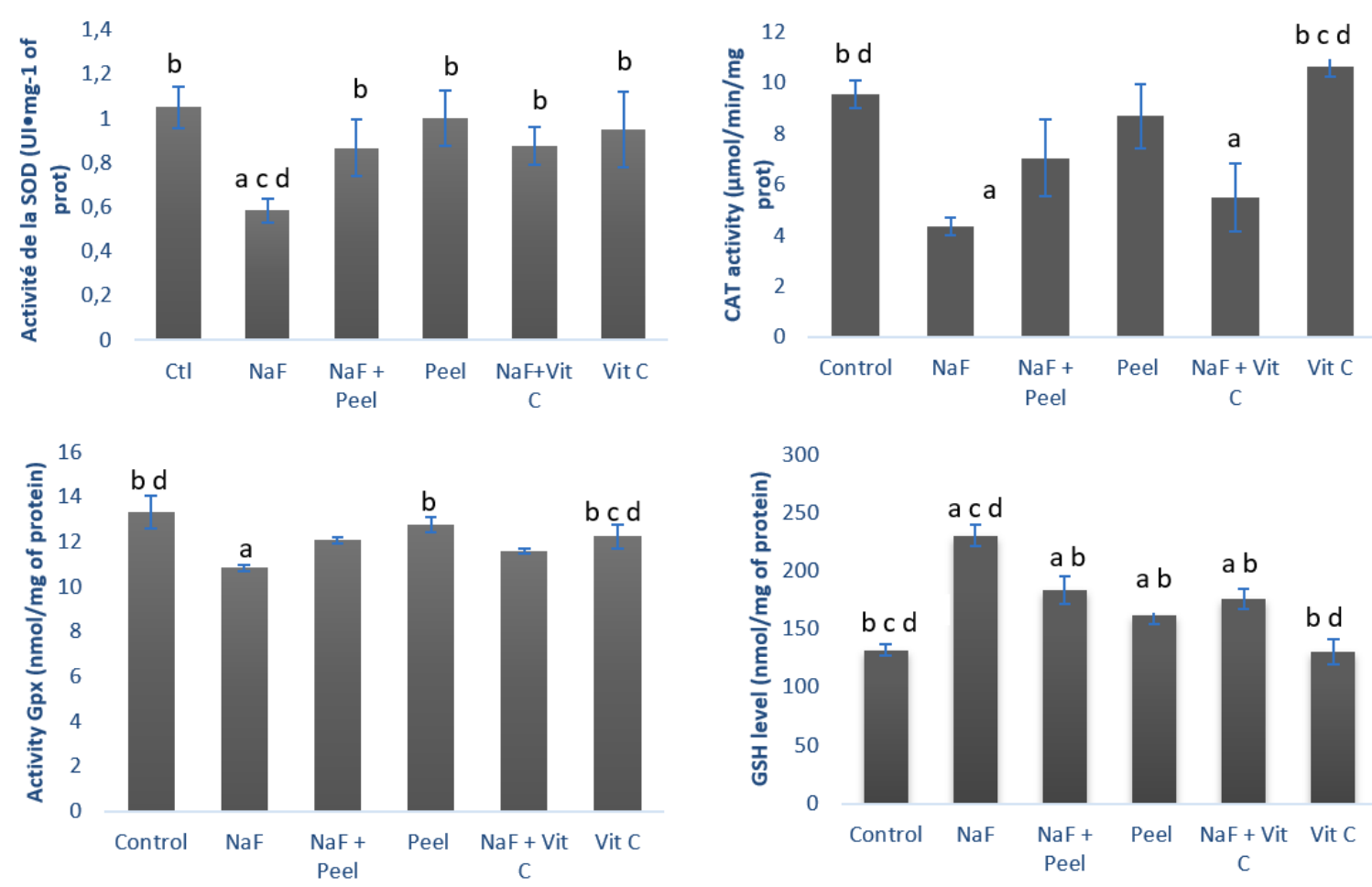

Figure 4. Protective effect of PPE on antioxidant enzyme activities. Different letters discriminate statistical differences between groups of parameters: a: compared to Ctrl, b: compared to NaF; c: compared to $\mathrm{NaF}+$ peel; d: compared to $\mathrm{NaF}+\mathrm{Vit} \mathrm{C}$. 
On the other hand, when cells were supplemented with PEE and NaF combined, we observed amelioration of SOD activity by $27 \%$ ( $\mathrm{p}<0.05$ ) compared to the NaF group. A reduction of CAT activity of this enzyme was observed in the NaF group by 55.24\% ( $p<0.05)$, while treatment with PPE restored the CAT activity significantly by $27.70 \%$ (Figure 4). Gpx activity was similar to previous enzymes, with a reduction of activity in the NaF group of 18.91 $\%(p<0.05)$ and a restoration of activity by $9.32 \%$. In our study, when IC50 NaF applied NaFinduced oxidative stress, the quantity of GSH in cells increased significantly by $74.27 \%$ ( $p$ $<0.05$ ) in the $\mathrm{NaF}$ group compared to the untreated group (control) while when $\mathrm{NaF}+\mathrm{PPE}$ treatment reduced the GSH content by $35.28 \%$ compared to NaF group.

\subsection{Discussion.}

Commonly known, pomegranate peel is a major source of phenolic compounds. The ellagitannins and anthocyanins are considered the most prevalent polyphenols in pomegranate peel as their content can reach $66 \%$ of the total polyphenols in the peel [46-47-48]. A previous study by our team using UHPLC performed the characterization of the phenolic compounds present in the methanolic pomegranate extracts. The results showed that the concentrations of punicalagin isomers, ellagic acid, and gallic acid were lower in the seed than peel [49]. In this present study, we choose to use methanol as a solvent of extraction, considering its superior extractability and possessing the highest phenolic content [50,51]. The obtained phenolics and flavonoids contents data confirm that the pomegranate peel fraction possesses the highest phenolic compounds compared to seed, which totally agrees with previous studies. Orak et al. compared the chemical and antioxidant properties in different parts of 'Hicaznar' pomegranate variety, widely grown in Turkey. The results demonstrated that peel is more effective than juice and seed extracts as a potential source of natural antioxidants [52]. Other studies by Derakhshan et al. compared pomegranates from three regions of Iran were analyzed for phenolic contents in the peel, seed and juice of their extracts. It was made clear that pomegranate peel showed the highest phenolics content [53]. The same results were found by Balli et al. in a recent study [54].

Two artificial radicals were chosen to evaluate the antioxidant capacity of pomegranate extracts (DPPH, ABTS). Data from DPPH assay were similar to data from previous works, a study by Liu et al. evaluating the antioxidant properties of pulp and peel showed that peel methanolic extract exhibits a lower value of scavenging activity: $\mathrm{EC}_{50}=12-25 \mathrm{mg} / \mathrm{mL}$ [55]. Another study by Amri et al. reported higher values EC50 $=0.84 \mathrm{mg} / \mathrm{mL}$ compared to edible and no edible pomegranates peel varieties in Tunisia [56]. Moreover, ABTS is another artificial radical widely used to estimate with higher currency the antioxidant capacity of food [45], results from the ABTS assay are in total agreement with those of literature, a study by Elfaleh et al. reported $\mathrm{EC}_{50}$ values of peel between $0.062-0.085 \mathrm{mg} / \mathrm{mL}$, and $0.40-0.48 \mathrm{mg} / \mathrm{mL}$ for seed extracts [57]. In general, In vitro antioxidant activity demonstrated that PPE exhibits superior radical scavenging compared to PSE. Radicals scavenging activity of pomegranate peel is mainly attributed to the antioxidative compounds. Numerous studies showed a high correlation between phenolic content and antioxidant capacity [52-58]. Phenolic compounds possess the capacity of donating hydrogen from their hydroxyl group, thus neutralizing free radicals by forming stable complexes [59,60]. Additionally, we evaluated the antioxidant activity by FRAP The ferric reducing antioxidant power (FRAP), a colorimetric method based on reducing the complex $\mathrm{Fe}^{3+}$ and ferricyanide complex to the ferrous form. As shown in (Table 2), peel extract showed high chelating activity compared to seed, the same results were reported in the 
literature [49-61]. The chelating capacity of PPE was also assessed using ferrous ions $\mathrm{Fe}^{2+}$ and reported as $\mu \mathrm{mol}$ EDTA equivalents per gram of dry weight; results as showed in (Table 2), demonstrated the good chelating ability of PPE, however, no identified chelating capacity of PSE was observed. Once they are deprotonated, phenolic compounds can play the role of chelators of various metals [62]. These results outline the potential effect of pomegranate peel extract on $\mathrm{NaF}$ toxicity in a tetrahymenna model. This protozoan has proven its efficiency in investigating the toxicity of different metals pollutants in aquatic environments $[63,64]$.

Toxicity in vitro tests showed that concentrations of $\mathrm{NaF}$ above $0.3 \mathrm{mmol}$ resulted in a significant decrease in cell viability. The present results are in total agreement with previous findings presented in the literature. A study by Ameermaja et al. shows that treatment of A549 human epithelial cells with $5 \mathrm{mM}$ of $\mathrm{NaF}$ alone caused a decrease in cell viability by 54\% [39]. Another study by Das et al. demonstrated that cell viability decreased by $50 \%$ when hepatocytes are treated with $\mathrm{NaF}$ at a dose of $100 \mathrm{mM}$ [22]. Results from another study showed that $\mathrm{NaF}$ inhibits cell growth to $48 \%$ in mouse ameloblast-derived cell line (LS8) at a dose of $0.2 \mathrm{mM}$, after 24 hours of treatment [65]. Dose-dependent and effect of $\mathrm{NaF}$ on cellular metabolism vary remarkably according to cell type [1]. Previous studies demonstrated that fluoride at micromolar concentrations could be a good promoter of cell proliferation in vitro. Nevertheless, higher concentrations can induce a decreased viability of cells [66-67]. Such an effect is mainly related to the role of fluoride as a trigger of apoptosis and necrosis process in a large type of cells [68]. Furthermore, treatment with PPE alone has not shown any significant toxicity effect up to $100 \mu \mathrm{g} / \mathrm{ml}$. Danesi et al. demonstrated that pomegranates fruit extract didn't show any toxicity up to $0.6 \mathrm{mg} / \mathrm{ml}$ when applied on HepG2 cells line [69].

Fluoride can penetrate the cytoplasmic membrane by simple diffusion, mainly by his non-ionic diffusion of $\mathrm{HF}$, which can explain the significate increase of fluoride concentration in the $\mathrm{NaF}$ cells group. In addition, the activity of calcium and potassium can markedly increase the accumulation of fluoride in cells [21]. On the other hand, when PPE treatment was applied in combination with $\mathrm{NaF}$, there was a significant decrease in intra-cellular fluoride content. Several studies have mentioned the beneficial effect of bioactive natural products on fluoride toxicity [70]. Sestili et al. reported that the preparations from part of Punica granatum showed a significant cytoprotective effect against $\mathrm{H}_{2} \mathrm{O}_{2}$ toxicity when applied in oxidatively injured mammalian cells [71]. Ghosh et al. reported that arjunolic acid exhibited a cytoprotective effect against NaF-cytotoxicity on hepatocytes [72]. Yet, the mechanism is still scarce. We suggest that the cytoprotective properties of a pomegranate can be a derivate of its antioxidants activities, especially from its polyphenolic constituents, especially its hydrolyzable tannins. A study by X.Li et al. demonstrated that pomegranate phenolic compounds:gallic acid, ellagic acid and punicalagin, were able to promote cell proliferation in human neuroblastoma cells (SH-SY5Y) [73]. Another study by Berköz \& Krośniak mentioned that punicalagin derivated from pomegranate peel may induce apoptosis in A549 cell line through mitochondria-mediated pathway [74]. Data from the cytoprotective effect promoted us to investigate further the effect of fluoride and the treatment by the PPE on the properties of the antioxidant enzyme. Previous studies mentioned the role of fluoride in the generation of $\mathrm{O}^{2-}$ in a large mitochondrial cell, enhancing a cascade of reactions leading to excessive production of ROS both in vitro [75] or in-vivo [76-77]. It has been shown that fluoride intake at high doses can alter the antioxidants enzymes activity by forming a complex with the co-factors of metallo-enzymes, blocking the activity of these enzymes [12]. 
It is noteworthy that superoxide dismutase (SOD) is the first cellular barrier against excessive free radicals generation by catalyzing superoxide radicals to $\mathrm{H}_{2} \mathrm{O}_{2}$ [78]. In addition, Catalase (CAT) can break down $\mathrm{H}_{2} \mathrm{O}_{2}$ into a molecule of water and oxygen [42]. According to our results, a significant effect on antioxidant enzymes activities was observed between the group treated $\mathrm{NaF}$ and PPE compared to the control group. Thus, treatment with $0.8 \mathrm{mmol}$ of sodium fluoride $(\mathrm{NaF})$ revealed that (CAT, SOD, and $\mathrm{Gpx}$ ) activities were decreased significantly ( $p$ 0.05), however, the level of GSH increased instead. GSH is a physiological antioxidant compound under stressful attacks by heavy metals. Mammalian kidney cells secret GSH that forms inert bonds with metals, leading to forming a GSH-Metal complex transportable by the $\mathrm{Na}+$ amino-acid cotransporter [79,80]. After treatment with $\mathrm{NaF}$ and PEE simultaneously, enzyme activities were ascertained to be restored to normal levels. The same effect was observed in the $\mathrm{NaF}$ and Vit $\mathrm{C}$ combined group. Besides, no significant effect was observed when cells are treated with PPE or Vit $\mathrm{C}$ alone.

\section{Conclusions}

In summary, this study showed that Punicalagin and ellagic are the predominant phenolic compounds found in pomegranate peel and showed high antioxidant properties. Our data indicate that exposure to sodium fluoride led to an imbalance of the antioxidant enzyme activities of T. pyriformis and increased intracellular fluoride content. In addendum, PPE may play a good natural protective agent by restoring the oxidant/antioxidant hemostasis. Our findings are in total agreement with the survey literature. However, further studies should be undertaking to understand the mechanisms behind the beneficial effect. Considered as a waste of food processing, pomegranate peel represents a promising alternative to attenuate fluoride toxicity.

\section{Funding}

This research received no external funding.

\section{Acknowledgments}

This research has no acknowledgments.

\section{Conflicts of Interest}

The authors declared no conflict of interest.

\section{References}

1. Agalakova, N.I.; Gusev, G.P. Molecular Mechanisms of Cytotoxicity and Apoptosis Induced by Inorganic Fluoride. ISRN Cell Biol. 2012, 2012, 1-16, https://doi.org/10.5402/2012/403835.

2. Johnston, N.R.; Strobel, S.A. Principles of fluoride toxicity and the cellular response: a review. Arch. Toxicol. 2020, 94, 1051-1069, https://doi.org/10.1007/s00204-020-02687-5.

3. Jiang, N.; Guo, F.; Sun, B.; Zhang, X.; Xu, H. Different Effects of Fluoride Exposure on the Three Major Bone Cell Types. Biol. Trace Elem. Res. 2020, 193, 226-233, https://doi.org/10.1007/s12011-019-01684-9.

4. Li, X.; Wang, J.; Zhang, H.; Xiao, L.; Lei, Z.; Kaul, S.C.; Wadhwa, R.; Zhang, Z. Low Dose of Fluoride in the Culture Medium of Cordyceps militaris Promotes Its Growth and Enhances Bioactives with Antioxidant and Anticancer Properties. J. Fungi 2021, 7, 342, https://doi.org/10.3390/jof7050342.

5. Chen, G.; Hu, P.; Xu, Z.; Peng, C.; Wang, Y.; Wan, X.; Cai, H. The beneficial or detrimental fluoride to gut microbiota depends on its dosages. Ecotoxicol. Environ. Saf. 2021, 209, 111732, 
https://doi.org/10.1016/j.ecoenv.2020.111732.

6. Rahmani, S.; Rezaei, M. Toxicity of fluoride on isolated rat liver mitochondria. J. Fluor. Chem. 2020, 239, 109636, https://doi.org/10.1016/j.jfluchem.2020.109636.

7. Shyam, R.; Chaluvaiah, M.B.; Kumar, A.; Pahwa, M.; Rani, G.; Phogat, R. Impact of dental fl uorosis on the oral health related quality of life among 11- to 14-year-old school children in endemic fluoride areas of Haryana (India). Int. Dent. J. 2020, 70, 340-346, https://doi.org/10.1111/idj.12567.

8. Al-omoush, S.A.; Al-tarawneh, S.; Abu-awwad, M.; Sartawi, S.; Elmanaseer, W.; Alsoleihat, F. Comparison of oral health indicators between two places of endemic dental fluorosis in Jordan. Saudi Dent. J. 2020, 1015, https://doi.org/10.1016/j.sdentj.2020.04.004.

9. Mirlean, N.; Roisenberg, A. Fluoride distribution in the environment along the gradient of a phosphatefertilizer production emission (southern Brazil). Environmental Geochemistry and Health 2007, 29, 179-187, https://doi.org/10.1007/s10653-006-9061-1.

10. Ramteke, L.P.; Sahayam, A.C.; Ghosh, A.; Rambabu, U.; Reddy, M.R.P.; Popat, K.M.; Rebary, B.; Kubavat, D.; Marathe, K. V.; Ghosh, P.K. Study of fluoride content in some commercial phosphate fertilizers. J. Fluor. Chem. 2018, 210, 149-155, https://doi.org/10.1016/j.jfluchem.2018.03.018.

11. Cooper, J.; Lombardi, R.; Boardman, D.; Carliell-Marquet, C. The future distribution and production of global phosphate rock reserves. Resour. Conserv. Recycl. 2011, 57, 78-86, https://doi.org/10.1016/j.resconrec.2011.09.009.

12. Laghzizil, A.; Elhrech, N.; Britel, O.; Bouhaouss, A.; Ferhat, M. Removal of fluoride from moroccan phosphate and synthetic fluoroapatites. J. Fluor. Chem. 2000, 101, 69-73, https://doi.org/10.1016/S00221139(99)00184-0.

13. Jaoudi, R. El; Cadi, M.A. El; Bouslimane, Y.; Fekhaoui, M.; Bouklouze, A.; Cherrah, Y. Fluoride content in well water in rural areas in Teneur en fluorures des eaux de puits des régions rurales au Maroc. 2014.

14. Ghosh, D.; Das, S.; Maiti, R.; Jana, D.; Das, U.B. Testicular toxicity in sodium fluoride treated rats: Association with oxidative stress. Reprod. Toxicol. 2002, 16, 385-390, https://doi.org/10.1016/S08906238(02)00038-2.

15. Chouhan, S.; Lomash, V.; Flora, S.J.S. Fluoride-induced changes in haem biosynthesis pathway, neurological variables and tissue histopathology of rats. J. Appl. Toxicol. 2010, 30, 63-73, https://doi.org/10.1002/jat.1474.

16. De la Fuente, B.; Vázquez, M.; Rocha, R.A.; Devesa, V.; Vélez, D. Effects of sodium fluoride on immune response in murine macrophages. Toxicol. Vitr. 2016, 34, 81-87, https://doi.org/10.1016/j.tiv.2016.03.001.

17. Saeed, M.; Malik, R.N.; Kamal, A. Fluorosis and cognitive development among children (6-14 years of age) in the endemic areas of the world: a review and critical analysis. Environ. Sci. Pollut. Res. 2020, 27, 25662579, https://doi.org/10.1007/s11356-019-06938-6.

18. Guan, Z.Z.; Wang, Y.N.; Xiao, K.Q.; Dai, D.Y.; Chen, Y.H.; Liu, J.L.; Sindelar, P.; Dallner, G. Influence of chronic fluorosis on membrane lipids in rat brain. Neurotoxicol. Teratol. 1998, 20, 537-542, https://doi.org/10.1016/s0892-0362(97)00136-0.

19. Inkielewicz-Stepniak, I.; Czarnowski, W. Oxidative stress parameters in rats exposed to fluoride and caffeine. Food Chem. Toxicol. 2010, 48, 1607-1611, https://doi.org/10.1016/j.fct.2010.03.033.

20. Maheshwari, N.; Qasim, N.; Anjum, R.; Mahmood, R. Ecotoxicology and Environmental Safety Fluoride enhances generation of reactive oxygen and nitrogen species, oxidizes hemoglobin, lowers antioxidant power and inhibits transmembrane electron transport in isolated human red blood cells. Ecotoxicol. Environ. Saf. 2021, 208, 111611, https://doi.org/10.1016/j.ecoenv.2020.111611.

21. Yan, X.; Yan, X.; Morrison, A.; Han, T.; Chen, Q.; Li, J.; Wang, J. Fluoride induces apoptosis and alters collagen I expression in rat osteoblasts. Toxicol. Lett. 2011, 200, 133-138, https://doi.org/10.1016/j.toxlet.2010.11.005.

22. Barbier, O.; Arreola-Mendoza, L.; Del Razo, L.M. Molecular mechanisms of fluoride toxicity. Chem. Biol. Interact. 2010, 188, 319-333, https://doi.org/10.1016/j.cbi.2010.07.011.

23. Das, J.; Ghosh, J.; Manna, P.; Sil, P.C. Taurine provides antioxidant defense against NaF-induced cytotoxicity in murine hepatocytes. Pathophysiology 2008, 15, 190, https://doi.org/10.1016/j.pathophys.2008.06.002.

24. Dec, K.; Ł, A.; Baranowska-bosiacka, I.; Pilutin, A.; Maciejewska, D.; Re, E. Chemosphere Pre-and postnatal exposition to $\mathrm{fl}$ uorides induce changes in rats liver morphology by impairment of antioxidant defense mechanisms and COX induction. 2018, 211, 112-119, https://doi.org/10.1016/j.chemosphere.2018.07.145.

25. Teixeira da Silva, J. a.; Rana, T.S.; Narzary, D.; Verma, N.; Meshram, D.T.; Ranade, S. a. Pomegranate biology and biotechnology: A review. Sci. Hortic. (Amsterdam). 2013, 160, 85-107, 
https://doi.org/10.1016/j.scienta.2013.05.017.

26. Magangana, T.P.; Makunga, N.P.; Fawole, O.A.; Opara, U.L. Processing factors affecting the phytochemical and nutritional properties of pomegranate (punica granatum L.) peel waste: A review. Molecules 2020, 25, 1-34, https://doi.org/10.3390/molecules25204690.

27. Karimi, M.; Sadeghi, R.; Kokini, J. Pomegranate as a promising opportunity in medicine and nanotechnology. Trends Food Sci. Technol. 2017, 69, 59-73, https://doi.org/10.1016/j.tifs.2017.08.019.

28. Jafari, T. Effects of pomegranate peel extract and vitamin E on oxidative stress and antioxidative capacity of hemodialysis patients: A randomized controlled clinical trial. J. Funct. Foods 2020, 72, 104069, https://doi.org/10.1016/j.jff.2020.104069.

29. Turrini, F.; Malaspina, P.; Giordani, P.; Catena, S.; Zunin, P.; Boggia, R. Traditional decoction and puae aqueous extracts of pomegranate peels as potential low-cost anti-tyrosinase ingredients. Appl. Sci. 2020, 10, 1-14, https://doi.org/10.3390/app10082795.

30. Eid, Y.; Kirrella, A.A.; Tolba, A.; El-Deeb, M.; Sayed, S.; El-Sawy, H.B.; Shukry, M.; Dawood, M.A.O. Dietary pomegranate by-product alleviated the oxidative stress induced by dexamethasone in laying hens in the pre-peak period. Animals 2021, 11, https://doi.org/10.3390/ani11041022.

31. Ruehle, M.D.; Orias, E.; Pearson, C.G. Tetrahymena as a unicellular model eukaryote: Genetic and genomic tools. Genetics 2016, 203, 649-665, https://doi.org/10.1534/genetics.114.169748.

32. Shaban, N.Z.; El-Kersh, M. a. L.; El-Rashidy, F.H.; Habashy, N.H. Protective role of Punica granatum (pomegranate) peel and seed oil extracts on diethylnitrosamine and phenobarbital-induced hepatic injury in male rats. Food Chem. 2013, 141, 1587-1596, https://doi.org/10.1016/j.foodchem.2013.04.134.

33. Singh, R.P.; Murthy, K.N.C.; Jayaprakasha, G.K. Studies on the Antioxidant Activity of Pomegranate ( Punica granatum ) Peel and Seed Extracts Using in vitro Models. J. Agric. Food Chem. 2002, 50, 81-86, https://doi.org/10.1021/jf010865b.

34. Zhishen, J.; Mengcheng, T.; Jianming, W. The determination of flavonoid contents in mulberry and their scavenging effects on superoxide radicals. Food Chem. 1999, 64, 555-559, https://doi.org/10.1016/S03088146(98)00102-2.

35. Porter, R.R. (C) 1958 Nature Publishing Group. Sep. Isol. fractions Rabbit gamma-globulin Contain. Antib. Antigen. Comb. sites 1958, 182, 670-671, https://doi.org/10.2307/3280933.

36. Ramos, I.I.; Gregório, B.J.R.; Barreiros, L.; Magalhães, L.M.; Tóth, I. V.; Reis, S.; Lima, J.L.F.C.; Segundo, M.A. Programmable flow system for automation of oxygen radical absorbance capacity assay using pyrogallol red for estimation of antioxidant reactivity. Talanta 2016, 150, 599-606, https://doi.org/10.1016/j.talanta.2015.12.061.

37. Oyaizu, M. Studies on products of browning reaction. Antioxidative activities of products of browning reaction prepared from glucosamine. Japanese J. Nutr. Diet. 1986, 44, 307-315, https://doi.org/10.5264/eiyogakuzashi.44.307.

38. Dinis, LM;Madeira, TCP and Almeida, V. Action of phenolic derivates (acetaminophen, salycilate, and 5aminosalycilate) as inhibitors of membrane lipid peroxidation and as peroxylradical scavengers. Arch Biochem Biophys 1994, 315, 161-169, https://doi.org/10.1006/abbi.1994.1485.

39. Fourrat, L.; Iddar, A.; Valverde, F.; Serrano, A.; Soukri, A. Effects of oxidative and nitrosative stress on Tetrahymena pyriformis glyceraldehyde-3-phosphate dehydrogenase. J. Eukaryot. Microbiol. 2007, 54, 338346, https://doi.org/10.1111/j.1550-7408.2007.00275.x.

40. Yang, Y.; Lin, X.; Huang, H.; Feng, D.; Ba, Y.; Cheng, X.; Cui, L. Sodium fluoride induces apoptosis through reactive oxygen species-mediated endoplasmic reticulum stress pathway in Sertoli cells. J. Environ. Sci. 2015, 30, 81-89, https://doi.org/10.1016/j.jes.2014.11.004.

41. Ameeramja, J.; Panneerselvam, L.; Govindarajan, V.; Jeyachandran, S.; Baskaralingam, V.; Perumal, E. Tamarind seed coat ameliorates fluoride induced cytotoxicity, oxidative stress, mitochondrial dysfunction and apoptosis in A549 cells. J. Hazard. Mater. 2016, 301, 554-565, https://doi.org/10.1016/j.jhazmat.2015.09.037.

42. Parmar, H.S.; Kar, A. Protective role of Citrus sinensis, Musa paradisiaca, and Punica granatum peels against diet-induced atherosclerosis and thyroid dysfunctions in rats. Nutr. Res. 2007, 27, 710-718, https://doi.org/10.1016/j.nutres.2007.09.003.

43. Beyer, W.F.; Fridovich, I. Assaying for superoxide dismutase activity: Some large consequences of minor changes in conditions. Anal. Biochem. 1987, 161, 559-566, https://doi.org/10.1016/0003-2697(87)90489-1.

44. Sinha, A.K. Colorimetric assay of catalase. Anal. Biochem. 1972, 47, 389-394, https://doi.org/10.1016/00032697(72)90132-7. 
45. Battenberg, E.F.; Hoffer, B.J.; Bloom, F.E.; Steiner, A.L.; Gessa, G.L.; Hoffer, B.J.; Siggins, G.R.; Hoffer, B. Selenium: Biochemical Role as a Component of Glutathione Peroxidase. 1962, 179, 588-590, https://doi.org/10.1126/science.179.4073.588.

46. Ellman, G.L. Tissue Sulfhydryl Groups. Am. J. Anal. Chem. 1959, 82, 70-77, https://doi.org/10.1016/00039861(59)90090-6.

47. Floegel, A.; Kim, D.O.; Chung, S.J.; Koo, S.I.; Chun, O.K. Comparison of ABTS/DPPH assays to measure antioxidant capacity in popular antioxidant-rich US foods. J. Food Compos. Anal. 2011, 24, 1043-1048, https://doi.org/10.1016/j.jfca.2011.01.008.

48. Wang, Z. Extract of Phenolics From Pomegranate Peels. Open Food Sci. J. 2011, 5, 17-25, https://doi.org/10.2174/1874256401105010017.

49. Gullón, P.; Astray, G.; Gullón, B.; Tomasevic, I.; Lorenzo, J.M. Pomegranate Peel as Suitable Source of High-Added Value Bioactives: Tailored Functionalized Meat Products. Molecules 2020, 25, 1-18, https://doi.org/10.3390/molecules25122859.

50. Panza, O.; Conte, A.; Del Nobile, M.A. Pomegranate By-Products as Natural Preservative to Prolong the Shelf Life of Breaded Cod Stick. Molecules 2021, 26, https://doi.org/10.3390/molecules26082385.

51. Sabraoui, T.; Khider, T.; Nasser, B.; Eddoha, R.; Moujahid, A.; Benbachir, M.; Essamadi, A. Determination of Punicalagins Content, Metal Chelating, and Antioxidant Properties of Edible Pomegranate (Punica granatum L) Peels and Seeds Grown in Morocco.International Journal of Food Science 2020, 2020, 4-11, https://doi.org/10.1155/2020/8885889.

52. Sandesh, P.; Velu, V.; Singh, R.P. Antioxidant activities of tamarind (Tamarindus Indica) seed coat extracts using in vitro and in vivo models. J. Food Sci. Technol. 2014, 51, 1965-1973, https://doi.org/10.1007/s13197013-1210-9.

53. El-Hadary, A.E.; Taha, M. Pomegranate peel methanolic-extract improves the shelf-life of edible-oils under accelerated oxidation conditions. Food Sci. Nutr. 2020, 8, 1798-1811, https://doi.org/10.1002/fsn3.1391.

54. Orak, H.H.; Yagar, H.; Isbilir, S.S. Comparison of antioxidant activities of juice, peel, and seed of pomegranate (Punica granatum L.) and inter-relationships with total phenolic, Tannin, anthocyanin, and flavonoid contents. Food Sci. Biotechnol. 2012, 21, 373-387, https://doi.org/10.1007/s10068-012-0049-6.

55. Derakhshan, Z.; Ferrante, M.; Tadi, M.; Ansari, F.; Heydari, A.; Hosseini, M.S.; Conti, G.O.; Sadrabad, E.K. Antioxidant activity and total phenolic content of ethanolic extract of pomegranate peels, juice and seeds. Food Chem. Toxicol. 2018, 114, 108-111, https://doi.org/10.1016/j.fct.2018.02.023.

56. Balli, D.; Cecchi, L.; Khatib, M.; Bellumori, M.; Cairone, F.; Carradori, S.; Zengin, G.; Cesa, S.; Innocenti, M.; Mulinacci, N. Characterization of Arils Juice and Peel Decoction of Fifteen Varieties of Punica granatum L . Antioxidants. 2020, 9, 238; https://doi.org/10.3390/antiox9030238.

57. Li, Y.; Guo, C.; Yang, J.; Wei, J.; Xu, J.; Cheng, S. Evaluation of antioxidant properties of pomegranate peel extract in comparison with pomegranate pulp extract. Food Chem. 2006, 96, 254-260, https://doi.org/10.1016/j.foodchem.2005.02.033.

58. Amri, Z.; Zaouay, F.; Lazreg-Aref, H.; Soltana, H.; Mneri, A.; Mars, M.; Hammami, M. Phytochemical content, Fatty acids composition and antioxidant potential of different pomegranate parts: Comparison between edible and non edible varieties grown in Tunisia. Int. J. Biol. Macromol. 2017, 104, 274-280, https://doi.org/10.1016/j.ijbiomac.2017.06.022.

59. Elfalleh, W.; Hannachi, H.; Tlili, N.; Yahia, Y.; Nasri, N.; Ferchichi, A. Total phenolic contents and antioxidant activities of pomegranate peel, seed, leaf and flower. J. Med. Plants Res. 2012, 6, 4724-4730, https://doi.org/10.5897/JMPR11.995.

60. Seeram, N.P.; Aviram, M.; Zhang, Y.; Henning, S.M.; Feng, L.; Dreher, M.; Heber, D. Comparison of antioxidant potency of commonly consumed polyphenol-rich beverages in the United States. J. Agric. Food Chem. 2008, 56, 1415-22, https://doi.org/10.1021/jf073035s.

61. Mustafa, R.A.; Hamid, A.A.; Mohamed, S.; Bakar, F.A. Total phenolic compounds, flavonoids, and radical scavenging activity of 21 selected tropical plants. J. Food Sci. 2010, 75, https://doi.org/10.1111/j.17503841.2009.01401.x.

62. Ge, X.; Jing, L.; Zhao, K.; Su, C.; Zhang, B.; Zhang, Q.; Han, L.; Yu, X.; Li, W. The phenolic compounds profile, quantitative analysis and antioxidant activity of four naked barley grains with different color. Food Chem. 2021, 335, 127655, https://doi.org/10.1016/j.foodchem.2020.127655.

63. Guo, C.; Yang, J.; Wei, J.; Li, Y.; Xu, J.; Jiang, Y. Antioxidant activities of peel, pulp and seed fractions of common fruits as determined by FRAP assay. Nutr. Res. 2003, 23, 1719-1726, https://doi.org/10.1016/j.nutres.2003.08.005. 
64. Khodr, H. Metal Chelation of Polyphenols Metal Chelation of Polyphenols. 2018, 6879, 190-203, https://doi.org/10.1016/S0076-6879(01)35243-6.

65. Sauvant, M.P.; Pepin, D.; Bohatier, J.; Groliere, C.A. Effects of chelators on the acute toxicity and bioavailability of aluminium to Tetrahymena pyriformis. Aquat. Toxicol. 2000, 47, 259-275, https://doi.org/10.1016/S0166-445X(99)00015-6.

66. Shi, J.; Ji, X.; Wu, Q.; Liu, H.; Qu, G.; Yin, Y.; Hu, L.; Jiang, G. Tracking Mercury in Individual Tetrahymena Using a Capillary Single-Cell Inductively Coupled Plasma Mass Spectrometry Online System. Anal. Chem. 2020, 92, 622-627, https://doi.org/10.1021/acs.analchem.9b03719.

67. Kubota, K.; Lee, D.H.; Tsuchiya, M.; Young, C.S.; Everett, E.T.; Martinez-Mier, E.A.; Snead, M.L.; Nguyen, L.; Urano, F.; Bartlett, J.D. Fluoride induces endoplasmic reticulum stress in ameloblasts responsible for dental enamel formation. J. Biol. Chem. 2005, 280, 23194-23202, https://doi.org/10.1074/jbc.M503288200.

68. García-Montalvo, E. a.; Reyes-Pérez, H.; Del Razo, L.M. Fluoride exposure impairs glucose tolerance via decreased insulin expression and oxidative stress. Toxicology 2009, 263, 75-83, https://doi.org/10.1016/j.tox.2009.06.008.

69. Aulestia, F.J.; Groeling, J.; Bomfim, G.H.S.; Costiniti, V.; Manikandan, V.; Chaloemtoem, A.; Concepcion, A.R.; Li, Y.; Ii, L.E.W.; Idaghdour, Y.; et al. Fluoride exposure alters $\mathrm{Ca} 2+$ signaling and mitochondrial function in enamel cells. Sci Signal 2020, 13, https://doi.org/10.1126/scisignal.aay0086.

70. Zuo, H.; Chen, L.; Kong, M.; Yang, Y.; Lü, P.; Qiu, L.; Wang, Q.; Ma, S.; Chen, K. The toxic effect of sodium fluoride on Spodoptera frugiperda 9 cells and differential protein analysis following NaF treatment of cells. Environ. Pollut. 2018, 236, 313-323, https://doi.org/10.1016/j.envpol.2018.01.054.

71. Danesi, F.; Kroon, P.; Saha, S.; de Biase, D.; D’Antuono, L.; Bordoni, A. Mixed Pro- and Anti-Oxidative Effects of Pomegranate Polyphenols in Cultured Cells. Int. J. Mol. Sci. 2014, 15, 19458-19471, https://doi.org/10.3390/ijms151119458.

72. Claudio, S.R.; Handan, B.A.; Gomes De Moura, C.F.; Viana, M.D.B.; Yamauchi, L.Y.; Aguiar, O.; Oshima, C.T.F.; Ribeiro, D.A. Role of polyphenols and nonpolyphenols against toxicity induced by fluoride: A comprehensive review. Eur. J. Cancer Prev. 2019, 28, 109-114, https://doi.org/10.1097/CEJ.0000000000000424.

73. Sestili, P.; Martinelli, C.; Ricci, D.; Fraternale, D.; Bucchini, A.; Giamperi, L.; Curcio, R.; Piccoli, G.; Stocchi, V. Cytoprotective effect of preparations from various parts of Punica granatum L. fruits in oxidatively injured mammalian cells in comparison with their antioxidant capacity in cell free systems. Pharmacol. Res. 2007, 56, 18-26, https://doi.org/10.1016/j.phrs.2007.02.003.

74. Ghosh, J.; Das, J.; Manna, P.; Sil, P.C. Cytoprotective effect of arjunolic acid in response to sodium fluoride mediated oxidative stress and cell death via necrotic pathway. Toxicol. Vitr. 2008, 22, 1918-1926, https://doi.org/10.1016/j.tiv.2008.09.010.

75. Li, X.; Liu, L.; Pischetsrieder, M. Pomegranate (Punica granatum L.) wine polyphenols affect Nrf2 activation and antioxidant enzyme expression in human neuroblastoma cells (SH-SY5Y). J. Funct. Foods 2017, 38, 140-150, https://doi.org/10.1016/j.jff.2017.08.048.

76. Berköz, M.; Krośniak, M. Punicalagin induces apoptosis in A549 cell line through mitochondria-mediated pathway. Gen Physiol Biophys 2020,39, 557-567, https://doi.org/10.4149/gpb_2020024.

77. Anuradha, C.D.; Kanno, S.; Hirano, S. Oxidative damage to mitochondria is a preliminary step to caspase-3 activation in fluoride-induced apoptosis in hl-60 cells. Free Radic. Biol. Med. 2001, 31, 367-73, https://doi.org/10.1016/s0891-5849(01)00591-3.

78. Abdel-Wahab, W.M. Protective effect of thymoquinone on sodium fluoride-induced hepatotoxicity and oxidative stress in rats. J. Basic Appl. Zool. 2013, 66, 263-270, https://doi.org/10.1016/j.jobaz.2013.04.002.

79. Raina, R.; Baba, N.A.; Verma, P.K.; Sultana, M.; Singh, M. Hepatotoxicity Induced by Subchronic Exposure of Fluoride and Chlorpyrifos in Wistar Rats: Mitigating Effect of Ascorbic Acid. Biol. Trace Elem. Res. 2015, 166, 157-162, https://doi.org/10.1007/s12011-015-0263-1.

80. Barbier, O.; Jacquillet, G.; Tauc, M.; Cougnon, M. Effect of Heavy Metals on , and Handling by , the Kidney. 2005, 2, 105-110, https://doi.org/10.1159/000083981.

81. Matthaiou, C.M.; Goutzourelas, N.; Stagos, D.; Sarafoglou, E.; Jamurtas, A.; Koulocheri, S.D.; Haroutounian, S. a.; Tsatsakis, A.M.; Kouretas, D. Pomegranate juice consumption increases GSH levels and reduces lipid and protein oxidation in human blood. Food Chem. Toxicol. 2014, 73, 1-6, https://doi.org/10.1016/j.fct.2014.07.027. 